\section{Distribution of HOMA-IR in Brazilian Subjects with Different Body Mass Indexes}

\section{To the editor}

$\mathrm{I}$

THE CLINICAL SETTING, assessment of insulin resistance (IR) can be made without any laboratory test, but by evaluating data such as weight or BMI, among others. However, in the last few years laboratories have been asked to provide direct or indirect measures of IR. Homeostatic model assessment (HOMA-IR) is a simple and inexpensive technique to evaluate IR from basal (fasting) glucose and insulin or C-peptide concentrations, validated against a variety of physiological methods (1-4). To validate the potential use of HOMA-IR values in clinical practice, it is important to establish its distribution in a sample of normoglycemic individuals from a population with the same genetic background (2). In this regard, we aim to describe the distribution of HOMA-IR values in a large sample of Brazilian population. We analyzed retrospectively fasting insulin and glucose levels in 1,898 Brazilian adults (25\% males, age range 18 -90 years). All had fasting glucose $<99 \mathrm{mg} / \mathrm{dL}$, none on insulin secretagogues or insulin use. Insulin levels were determined by a time-resolved fluroimmunoassay (Perkin Elmer). HOMA-IR was calculated with the following: fasting serum insulin $(\mu \mathrm{U} / \mathrm{ml})+$ fasting plasma glucose $(\mathrm{mmol} / \mathrm{l}) / 22.5$ (1). In the entire group the mean HOMA-IR was $1.8 \pm 0.9(\mathrm{M} \pm \mathrm{SD})$. Taking into account the relationship between adiposity and insulin levels and IR, we stratified the group according to the BMI $\left(\mathrm{kg} / \mathrm{m}^{2}\right)$ in terciles: $<25(\mathrm{n}=883) ; 25-30(\mathrm{n}=624)$ and $>30(\mathrm{n}=391)$ (table 1$)$. A recent publication in a group of 312 non-obese, normoglicemic Brazilian subjects found a mean HOMA-IR of 1.7, and a threshold value for insulin resistance of 2.71 (3). The use of HOMA -IR to quantify insulin sensitivity can be helpful in clinical practice for comparisons of insulin sensitivity, gathering of longitudinal data in subjects at risk for development of abnormal glucose tolerance. Also, HOMA -IR can be used to assess longitudinal changes of IR in patients with diabetes in order to examine the natural history of the disease and to assess the effects of treatment, as demonstrated for example in the U.K. Prospective Diabetes Study (UKPDS) (5). Our results can be useful as a reference for further Brazilian studies using HOMA-IR values as a measure of IR in this particular population.

\section{carta ao editor}

Maria T. Ghiringhello

José Gilberto H. Vieira

Teresinba T. Tachibana

Cláudia Ferver

Rui M.B. Maciel

Patricia H.C. Amioka

Omar M. Hauache

Cláudia H.M.C. de Oliveiva

Cristina Khawali

Andvé F. Reis

Diabetes Center, Fleury Institute, (MTG, JGHV,TTT, CF, RMBM, PHCA, OMH, CHMCO, CK, AFR) São Paulo, SP e Disciplina de Endocrinologia, Departamento de Medicina, Escola Paulista de Medicina (UNIFESP), (JGHV, RMBM, OMH, CK, AFR). São Paulo, SP

Table 1. Distribution and mean \pm SD in a group of 1,898 Brazilian adults with normal fasting glucose levels.

\begin{tabular}{lccc}
\hline \multicolumn{4}{c}{ HOMA-IR } \\
\hline BMI $\left(\mathbf{k g} / \mathrm{m}^{2}\right)$ & $\mathbf{n}$ & Mean \pm SD & Distribution $(95 \% \mathrm{Cl})$ \\
\hline$<25$ & 883 & $1.2 \pm 0.65$ & $0.4-2.9$ \\
25 a 30 & 624 & $1.8 \pm 0.98$ & $0.4-4.3$ \\
$>30$ & 391 & $2.9 \pm 1.6$ & $0.7-8.2$ \\
\hline
\end{tabular}




\section{REFERENCES}

1. Matthews DR, Hosker JP, Rudenski AS, Naylor BA, Treacher DF, Turner RC. Homeostasis model assessment: insulin resistance and beta-cell function from plasma glucose and insulin concentrations in man. Diabetologia $1985 ; 28: 412-9$

2. Wallace TM, Levy JC, Matthews DR. Use and abuse of HOMA modeling. Diabetes Care 2004;27:1487-95.

3. Geloneze B, Repetto EM, Geloneze SR, Tambascia MA, Ermetice MN. The threshold value for insulin resistance (HOMA-IR) in an admixtured population IR in the Brazilian Metabolic Syndrome Study. Diabetes Res Clin Pract 2006;72:219-20.
4. Stern SE, Williams K, Ferrannini E, DeFronzo RA, Bogardus C, Stern MP. Identification of individuals with insulin resistance using routine clinical measurements. Diabetes 2005:54:333-9.

5. UKPDS Group: U.K. Prospective Diabetes Study 16: Overview of 6 years' therapy of type II diabetes: a progressive disease. Diabetes 1995;44:1249-58.

\section{Address for correspondance:}

André F. Reis

Av. Gal. Waldomiro de Lima 508

04344-070 São Paulo, SP

Fax: (1 1 ) 5014-7425

E-mail: andre.reis@fleury.com.br

\section{ERRATUM}

Na edição de Abril de 2006, o artigo de Luciana Bahia e colaboradores - "O Endotélio na Síndrome Metabólica" (Arq Bras Endocrinol Metab 2006; 50/2:291-303), por uma falha na diagramação, foi impresso com o endereço errado da Instituição.

O endereço correto é:

Laboratório de Pesquisas em Microcirculação

Universidade do Estado do Rio de Janeiro/UERJ 